\title{
"The effect of Lithuanian household income on the choice of non-formal education of children through sports and related costs"
}

\begin{tabular}{|c|c|}
\hline AUTHORS & Vilma Čingienė (D https://orcid.org/0000-0002-4475-3528 \\
\hline ARTICLE INFO & $\begin{array}{l}\text { Vilma Čingienè (2020). The effect of Lithuanian household income on the choice } \\
\text { of non-formal education of children through sports and related costs. Innovative } \\
\text { Marketing , 16(1), 11-18. doi:10.21511/im.16(1).2020.02 }\end{array}$ \\
\hline DOI & http://dx.doi.org/10.21511/im.16(1).2020.02 \\
\hline RELEASED ON & Monday, 03 February 2020 \\
\hline RECEIVED ON & Wednesday, 01 January 2020 \\
\hline \multirow[t]{2}{*}{ ACCEPTED ON } & Friday, 31 January 2020 \\
\hline & $((c))_{\text {EY }}$ \\
\hline LICENSE & $\begin{array}{l}\text { This work is licensed under a Creative Commons Attribution } 4.0 \text { International } \\
\text { License }\end{array}$ \\
\hline JOURNAL & "Innovative Marketing " \\
\hline ISSN PRINT & $1814-2427$ \\
\hline ISSN ONLINE & $1816-6326$ \\
\hline PUBLISHER & LLC "Consulting Publishing Company "Business Perspectives" \\
\hline FOUNDER & LLC "Consulting Publishing Company "Business Perspectives" \\
\hline & ニシニ \\
\hline NUMBER OF REFERENCES & NUMBER OF FIGURES \\
\hline 35 & 0 \\
\hline
\end{tabular}

(c) The author(s) 2022. This publication is an open access article. 


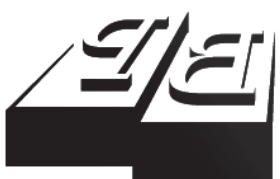

BUSINESS PERSPECTIVES

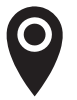

LLC "CPC "Business Perspectives" Hryhorii Skovoroda lane, 10, Sumy, 40022, Ukraine

www.businessperspectives.org

Received on: $1^{\text {st }}$ of January, 2020 Accepted on: $31^{\text {st }}$ of January, 2020

() Vilma Čingienė, 2020

Vilma Čingiené, Professor, Faculty of Public Governance, Mykolas Romeris University, Lithuania.

\section{(ㄷ)(i)}

This is an Open Access article, distributed under the terms of the Creative Commons Attribution 4.0 International license, which permits unrestricted re-use, distribution, and reproduction in any medium, provided the original work is properly cited.

Vilma Čingienė (Lithuania)

\title{
THE EFFECT OF LITHUANIAN HOUSEHOLD INCOME ON THE CHOICE OF NON-FORMAL EDUCATION OF CHILDREN THROUGH SPORTS AND RELATED COSTS
}

\begin{abstract}
Lithuanian government attempts to create equal opportunities for children who are brought up in different economic, social, and cultural conditions. The income of the majority of Lithuanian citizens still falls behind the European average. This study aims to examine the effect of household income on the choice of non-formal education activity of children and the costs of participation in sports. A questionnaire survey was public used on a website. Vilnius households $(\Sigma=136)$ were those whose 3-7 years old children were enrolled in non-formal sports activities. The survey aimed to find out the effect of household income on the selection of children's non-formal sports education. Results showed that the importance level of a sports club, the sport, or activity selection criteria are more expressed in families with lower income. Survey revealed the annual (nine months) ten categories of expenses incurred by parents. The average parental costs for children's sports activities per nine months amount to EUR 550, consisting of the membership fees and other costs. Parents tend to finance children's non-formal education through sport irrespective of household income, i.e., parental predispositions towards their children's participation in sports are much stronger compared to incurred expenses on sports activities.
\end{abstract}

\section{Keywords}

JEL Classification

Author
Contributions household income, non-formal education, sports, sports expenses

\section{D13, M31,G50, L67}

Conceptualization, V.C.; Data curation, V.C.; Formal analysis, V.C.; Investigation, V.C.; Methodology, V.C.; Project administration, V.C.; Supervision, V.C.; Validation, V.C.; Visualization, V.C.; Writing - original draft, V.C.; Writing - review \& editing, V.C.

\section{INTRODUCTION}

Children and Youth Socialization Program (2010) states that children and youth have limited possibilities to participate in educational activities they prefer and enjoy purposeful and meaningful leisure due to the difficult economic situation in Lithuania. Lithuanian government attempts to create equal opportunities for children who are brought up in different economic, social, and cultural conditions. According to the survey conducted by Žygaitienè and Stankevičienè (2015), one-fourth of parents make non-formal education arrangements for their children and give priority to sports activities. A study by Adaškevičienè and Strazdienè (2013) revealed that after-school sports activities and exercising are very important for children because through the sport they lay the foundations for a healthy lifestyle, gain knowledge about human beings as social and biological creatures, learn to combine studies and active leisure.

Children's non-formal education is mainly financed by local authorities in Lithuania. Fees paid by parents made only 8 percent of munic- 
ipal allocations (Kvieskienè \& Petronienė, 2007). Since 2015, following the resolution of the Lithuanian government, targeted funding for children's non-formal education, including sports activities, a basket of EUR 15 has been used. The key indicator of non-formal education costs is the average expenses per child. After the introduction of the basket, 565 new non-formal education institutions were established, and over 2,000 non-formal education programs were registered, mainly in the areas of sport, dance, music, and civic education (Putys, 2016).

The income of the majority of Lithuanian citizens still falls behind the European average. According to Eurostat data of 2016, the minimum wage in Lithuania is among the lowest in the European Union. There is also a big income inequality between different population groups. In Lithuania, the household income is mainly spent on necessities, not for healthy nutrition or meaningful leisure.

Although there are some attempts to provide equal opportunities to all Lithuanian children, the possibility for a child to attend after-school activities depends on the financial capacities of the child's family. Introduction of baskets for non-formal education alleviated the financial burden on the parents; however, the costs include not only the price of non-formal education services but also sportswear, equipment, sports camps, etc.

The novelty and originality of the study are based on an attempt to fill the gap of knowledge on sports consumption at the local level in Lithuania. This study aims to examine the effect of household income on the choice of non-formal education activity and the costs of participation in sports.

\section{LITERATURE REVIEW}

\subsection{Children's non-formal education situation in Lithuania}

Different definitions are used in the Republic of Lithuania legislation to describe the activities chosen by children according to their preferences: children's non-formal education, informal education, activities for children, after-school activities, etc. (The Concept of Children's Non-Formal Education, 2012). Children's non-formal education can be described as a part of regular education aimed to develop skills in children and youth (intellectual, artistic, athletic, social, etc.) Nonformal education is organized based on the principles of formal education to create conditions for all children to meet their interests, satisfy their needs, and develop skills (Barkauskaitè, 2004). Nevertheless, Moldovan and Bocoş-Binţinţan (2015) suggest reconsideration and re-signification of the concept of non-formal education, taking into account the new educational paradigms, curriculum, and methodological evolutions, etc.

The provisions of creative and accessible education are laid down in the European Parliament resolution on delivering lifelong learning for knowledge, creativity, and innovation - implementation of the 'Education and Training 2010 Work Program'. The national education strategy (2013-2022) aims to develop non-formal education to ensure the child's self-knowledge, create the conditions for self-expression, and to provide conditions for gaining the experience of creation, non-traditional learning, citizenship, and learn other important lessons.

Non-formal education of children through sports is delivered following the Sport Education Recommendations approved by the Department of Physical Education and Sports under the Government of the Republic of Lithuania (2014). A plan of sports education programs supporting formal education was developed following the recommendations. Sports schools, which supplement the formal education, are usually registered as educational institutions.

Non-formal education activities must be accessible in order to involve as many children into non-formal education as possible. The location of the child's home is the factor of primary importance in the selection of non-formal education providers. Usually, institutions located in the neighborhood are selected. The second important 
factor for the selection of non-formal education institutions and program is the family's means because not all children can afford to participate in non-formal education. Different funding allocated by regions and fields of activities does not guarantee the accessibility of non-formal education to all children and equal social inclusion (Kvieskienè \& Petroniené, 2007). Skirmantienës (2013) survey revealed the weaknesses in the administrative organization of non-formal education: insufficient variety of education activities in institutions, underfunding, poor condition of facilities, little dissemination of information, shortage of qualified specialists, limited possibilities for children with special needs and those coming from families at risk. According to Morkūnienè (2012), specialized schools of non-formal education (music, sport, etc.) do not guarantee equal opportunities for meeting the self-expression needs of all children because children are selected according to their abilities. The funding model Money Follows the Child, the so-called children education basket, was designed to promote the development of children's non-formal education and to solve the funding problems. The basket consists of the money allocated for the child's education according to the chosen education program over a specified period. The amount is calculated in the manner prescribed by the law. Only one non-formal education program selected by the child's family can be financed from the municipal allocations for non-formal education. The selected financing model stimulated the emergence of non-formal education institutions and the overall growth of non-formal education providers and the supply of programs. It should be noted that only school children enjoy the basket for non-formal education, whereas pre-school children do not have access to this funding.

Ruškus, Žvirdauskas, and Stanišauskienè (2009) noted that very few pre-school children (under seven years old) participate in non-formal education activities. The cooperation of pre-school education and non-formal education institutions is insufficient, and this lack of collaboration limits the benefits that could be enjoyed by all groups: children, parents, and teachers. In summary, there are seen accessibility and funding problems in the delivery of non-formal education both to school-children and pre-school children.

\subsection{Household budget structure in Lithuania}

Household income, consumption, and saving have become an important subject of public discussion. A private household changes constantly in terms of size, purchasing power, employment, and social status. Such changes are significant affect the economic functions of the household. The social status of persons belonging to the household influences the changes in consumption.

The research focus on sports consumption attracts special attention in various countries. The first studies examining the patterns of sports participation and consumption started from the mid1960's in the United Kingdom (Lamb, Asturias, Roberts, \& Ve Brodie, 1992). Summers, Johnson, and Ve Kanoyangwa (2007) tried to understand and explain the teenagers' sports consumption motivations in Australia. Sports consumption and participation models in Spain indicated the positive influence of gender and age (Lera-López \& Rapún-Gárate, 2007). Different factors affecting sport-related consumer expenditures were revealed in Turkey (Candemir \& Zalluhoğlu, 2012). Wicker et al. (2010) revealed that the sports expenditures of adult members of non-profit sports clubs in Germany are based on their strong financial status. Consequently, the Federal Ministry of the Interior of Germany and the Federal Institute of Sport Science funded a research project which aimed to determine sport-related consumption of private households in Germany for the 2010 (Preuss, Alfs, \& Ahlert, 2012). The collected data were valuable not only for sports science, but also for economically oriented policy counseling as well as for establishing a sports satellite account for Germany, as was indicated by the European Commission White Paper on Sport (2007).

The overall view of household expenses makes it possible to reveal the level of well-being and prosperity in the country. Household decisions regarding consumption and spending is an important factor determining the economic progress and prosperity because of consumption and spending influence on the processes of capital accumulation and economic growth. The population's standard of living is determined by the distribution of consumption costs. Food expenditure is one of the 
most important indicators as it shows the living standards of the country's population, i.e., the less money is spent on food compared to other expenditure, the higher is the living standard. According to Eurostat data, Lithuanian people spent the most on food, soft drinks, and transportation, whereas the expenditure for educations made only 0.5 percent and was among the lowest in Europe. Such distribution of expenditure can be explained by the minimum salary, which is some of the lowest in Europe (Eurostat, 2016). Lithuania falls behind its neighbors by the average salary: in Q2 2016, it was EUR 838 in Latvia and as high as EUR 1,163 in Estonia, while in Lithuania, it was only EUR 772 (Statistics Lithuania, 2016).

Consumption is related to the number of children in the household. Consumption increases with every new child in the family, but the increase is only felt with the second child. In families with more than two children, the consumption remains rather steady. According to Taks, Renson, and Ve Vanreusel (1999), the families with more children spend more on the sport. In general, private consumption possibilities improve with the growth of income. According to Gratton and Taylor (1988), higher income ensure higher consumption, i.e., the level of consumption on leisure and sports services becomes a catalyst of the economy.

There is a high-income inequality in Lithuania, a big gap between high earning groups and the least earning groups of the society (Aidukaite, 2009; Lisauskaite, 2010; Lithuania: National Reform Programme, 2011; Balvočiūté, 2014). The growing differentiation of income leads to growing dissatisfaction and social tension. Although the overall standard of living is becoming higher, the situation of some societal groups does not improve. Especially wide gaps are observed in the areas of recreation and culture, home furnishings, acquisition of clothing and footwear. People with the lowest income spend the major part of their earnings on everyday needs and can spend only a very small amount on recreation, culture, education, and health care - the most important areas for the quality of human life.

During the economic crisis (2008-2009), the consumption went down by 20 percent in the group of non-essential goods and services (Lydeka \& Žaliauskas, 2012). The situation changed with the economic recovery. According to Statistics Lithuania, in 2016, the average household consumption expenditure equaled to EUR 298 per capita per month (Table 1). Compared to 2012, the monthly consumption expenditure grew by 20.3 percent, or EUR 50. During four years, the largest increase was observed in household consumption expenditure on recreation and culture, furnishings, household equipment, etc. In 2016, household expenditure on food (including consumption in kind, but excluding money spent in cafés, restaurants, and canteens) made up almost a third (31.5 percent) of the total consumption expenditure, or, on average, EUR 94 per capita per month. In 2016, compared to 2012, household expenditure on meals at home grew by 12.2 percent, while the relative share (weight) in the total consumption expenditure decreased by 2.3 percentage points. In 2016, the expenditure on recreation and culture equaled EUR 19 per capita per month. Compared to 2012, the expenditure on recreation and culture grew by 57.9 percent, and the share in the total consumption expenditure increased by 1.5 percentage points.

Table 1. Average consumption expenditure and its structure in 2012 and 2016

Source: https://osp.stat.gov.lt/informaciniai-pranesimai?articleld=5151985

\begin{tabular}{|c|c|c|c|c|}
\hline & \multicolumn{2}{|c|}{$\begin{array}{c}\text { Average } \\
\text { consumption } \\
\text { expenditure } \\
\text { per capita per } \\
\text { month, EUR }\end{array}$} & \multicolumn{2}{|c|}{$\begin{array}{c}\text { Consumption } \\
\text { expenditure, } \\
\text { percent }\end{array}$} \\
\hline & 2012 & 2016 & 2012 & 2016 \\
\hline $\begin{array}{l}\text { Total consumption } \\
\text { expenditure }\end{array}$ & 247.4 & 297.5 & 100.0 & 100.0 \\
\hline $\begin{array}{l}\text { Food products and non- } \\
\text { alcoholic beverages }\end{array}$ & 83.5 & 93.7 & 33.7 & 31.5 \\
\hline $\begin{array}{l}\text { Alcoholic beverages and } \\
\text { tobacco products }\end{array}$ & 8.5 & 11.8 & 3.4 & 4.0 \\
\hline Clothing and footwear & 16.3 & 20.7 & 6.6 & 7.0 \\
\hline $\begin{array}{l}\text { Housing, water, electricity, } \\
\text { gas, and other fuels }\end{array}$ & 44.4 & 42.3 & 18.0 & 14.2 \\
\hline $\begin{array}{l}\text { Furnishings, household } \\
\text { equipment, and routine } \\
\text { maintenance of the house }\end{array}$ & 11.0 & 16.2 & 4.4 & 5.4 \\
\hline Health care & 14.5 & 19.8 & 5.9 & 6.6 \\
\hline Transport & 25.5 & 30.9 & 10.3 & 10.4 \\
\hline Communications & 9.3 & 12.7 & 3.7 & 4.3 \\
\hline Recreation and culture & 12.1 & 19.1 & 4.9 & 6.4 \\
\hline Education & 2.4 & 2.4 & 1.0 & 0.8 \\
\hline $\begin{array}{l}\text { Hotels, cafes, and } \\
\text { restaurants }\end{array}$ & 7.8 & 10.8 & 3.1 & 3.6 \\
\hline $\begin{array}{l}\text { Miscellaneous goods and } \\
\text { services }\end{array}$ & 12.3 & 17.3 & 5.0 & 5.8 \\
\hline
\end{tabular}




\section{METHODS}

A questionnaire survey was used for the study. The questionnaire was designed based on household expenditure on sports in Germany (Preuss \& Alfs, 2013) and the analysis of Lithuanian consumers' expenditure on sports (Čingienè, 2015). The questionnaire consists of two blocks: 1) demographic data; 2) questions covering the children's after-school activity by cost categories. The questionnaire is made of 25 questions. The questionnaire was made public on a website. The survey subjects were 136 parents from Vilnius whose 3-7 years old children were enrolled in non-formal sports activities. The survey was conducted in October-November 2016.

The collected data were processed by SPSS 22.0 program (Statistical Package for Social Sciences). Respondents' expenditures on non-formal education activities of children are presented by average amounts, standard deviations, minimum and maximum amounts. The comparison of groups by family income is made by means of Chi-square statistics. The selected significance level $p=0.05$.

\section{RESULTS}

One hundred thirty-six survey subjects from Vilnius city were distributed as follows: 32 men (23.5\%) and 104 women $(76.5 \%)$. The $30-39$ age group was the biggest (103 subjects) followed by the 40-49 age group (24 subjects) and the smallest 21-29 age group ( 9 subjects). Most of the subjects were married (121 subjectы); some were single (9 subjects) or divorced (6 subjects). According to the Statistics Lithuania (2015), the households consisting of one adult and a child/children (economically inactive individuals under 18 are regarded as children) face the highest risk of poverty; the risk increases with a bigger number of children. The majority of the subjects had a higher university education (110 subjects). Other groups were with higher non-university education (18 subjects) and secondary education (8 subjects). By employment, the subjects were distributed as follows: specialists/employees (92 subjects), managers (24 subjects), business owners (7 subjects), workers (7 subjects), farmers (1 subject), and housewives (5 subjects). In short, the majority of the subjects were active in the labor market.
The monthly income per person was rather high because 31 subjects specified EUR 751-1,500 per family member per month, 45 subjects marked EUR 501-750; however, 58 subjects reported the monthly income per family person below EUR 500. The majority of respondents stated their active engagement in sports: going to sports clubs, exercising at home (74 subjects). Onefifth of respondents stated that they were not actively engaged in sports but were interested in sports. Although parental example significantly influences the child's interest in sports and selection of sports activities, more than onethird of respondents' children neither participated nor were interested in sports (42 subjects). According to Lenartowicz (2013), the sports practices and tastes are quite distinct according to class-based patterns.

The survey results revealed that usually children exercise in the kindergarten and basketball is the most common activity (116 children); other sports include karate/martial arts, swimming. It should be noted that many children are involved not in one, but in two or three after-school activities, which subsequently increase the household spending. Children (89) usually attend sports sessions 1-2 times a week, but almost one-third of the children (40) have training sessions 3-4 times a week. Almost half of the children have been training for 1-2 years (60 subjects), a smaller portion (45) less than three years, and more than one-fifth of the respondents have been training for three and more years.

The survey aimed to find out the effect of household income on the selection of children's non-formal sports education. This effect was evaluated by nine criteria (Table 2). The child's wishes, and the location of sports activities are very important in the selection of the sports club, the sport or activity, irrespective of the household income level. About 60 percent of parents in households with EUR 500 per family member did not attach importance to recommendations or popularity of the sport but consider the coach important for their choice. Camiré, Trudel, and Forneris (2014) highlight the importance of the specific strategies of sports coachers, which facilitate positive your development and extend 
the learning process by participating in learning communities. Parents in households with more than EUR 500 per family member noted the importance of the coach and also the quality of services. Although the price-quality ratio was more important to households with lower income, both groups of respondents did not have a firm opinion on this issue. Both groups gave almost the same answers regarding the selection of sports activities by the child's abilities and talent. The price of sports activities was not important for families with higher income but was important to half of the families with lower income.

The summary of the survey results leads to the conclusion that the importance level of a sports club, the sport, or activity selection criteria are more expressed in families with lower income. In families with higher income, a more differentiated evaluation is observed.

In the next stage of the survey, it was aimed to reveal the annual (nine months) expense incurred by parents by the following categories: footwear, sportswear, sports equipment, participation fees, health insurance, travel costs, vitamins, and camps. The survey results revealed that the highest costs were monthly fees (EUR 50 per month), amounting to EUR 450 per year (nine months). Other highest average expenditure categories (EUR 10-30) were: life and injury insurance, regular trips to training sessions by car, and supplements and vitamins. The spending in more than half expenditure categories was up to EUR 10 per year (Table 3).
Table 3. Annual (nine months) parental expenses for children's sports activities

\begin{tabular}{|c|c|c|c|c|}
\hline No & $\begin{array}{c}\text { Expenditures category, } \\
\text { euros }\end{array}$ & $\mathbf{N}$ & $\begin{array}{l}\text { Mean, } \\
\text { euros }\end{array}$ & $\begin{array}{l}\text { Standard } \\
\text { deviation }\end{array}$ \\
\hline 1 & $\begin{array}{l}\text { Sports footwear (exclusively } \\
\text { for sports purposes only) }\end{array}$ & 133 & 8.90 & \pm 18.05 \\
\hline 2 & Sports clothing & 133 & 3.18 & \pm 6.81 \\
\hline 3 & $\begin{array}{l}\text { Sporting equipment, } \\
\text { equipment (e.g., basketball } \\
\text { balls, diving glasses, baseball } \\
\text { sticks, etc.) }\end{array}$ & 135 & 8.52 & \pm 42.64 \\
\hline 4 & $\begin{array}{l}\text { Regular trips to training } \\
\text { sessions by car }\end{array}$ & 130 & 16.25 & \pm 56.13 \\
\hline 5 & $\begin{array}{l}\text { Trips to the competition } \\
\text { by car (e.g., tournaments, } \\
\text { events, etc.) }\end{array}$ & 129 & 5.28 & \pm 22.84 \\
\hline 6 & Annual membership fee & 132 & 8.83 & \pm 35.85 \\
\hline 7 & Monthly membership fee & 130 & 49.53 & \pm 140.82 \\
\hline 8 & Life and injury insurance & 128 & 28.27 & \pm 86.25 \\
\hline 9 & Sports camps & 133 & 8.83 & \pm 35.64 \\
\hline 10 & Food supplements, vitamins & 136 & 11.78 & \pm 47.12 \\
\hline
\end{tabular}

The analysis of the survey results revealed that 17 subjects spent on average EUR 60 on footwear, the amount much higher than the average. Some parents had not incurred any expense on sportswear (19 subjects) and sports equipment (56 subjects). Although the average costs of trips to training sessions by car belong to the second-highest expenditure category, 107 subjects had not incurred any expense; presumably, children go to training sessions by public transport or on foot. The location criterion is important in this case. One hundred ten subjects stated they had not incurred any expense for trips to competitions. 2-3 events are organized per year, and sport education institutions cover children's transportation costs. Seventynine subjects spent EUR 15 on annual membership fees; this amount is about half the annual ex-

Table 2. Sports club, the sport, or activity selection criteria importance level by two groups of subjects according to household income per family member

\begin{tabular}{|c|c|c|c|c|c|c|c|}
\hline \multirow[b]{2}{*}{ No } & \multirow[b]{2}{*}{ Choices } & \multicolumn{3}{|c|}{ Up to 500 euro } & \multicolumn{3}{|c|}{ More than 500 euro } \\
\hline & & $\begin{array}{l}\text { Very } \\
\text { important }\end{array}$ & Important & $\begin{array}{c}\text { Not } \\
\text { important }\end{array}$ & $\begin{array}{c}\text { Very } \\
\text { important }\end{array}$ & Important & $\begin{array}{c}\text { Not } \\
\text { important }\end{array}$ \\
\hline 1 & Children's wishes & $87.9 \%$ & $1.7 \%$ & $10.3 \%$ & $78.9 \%$ & $10.5 \%$ & $10.5 \%$ \\
\hline 2 & Location of sports activities & $79.3 \%$ & $10.3 \%$ & $10.3 \%$ & $68.4 \%$ & $22.4 \%$ & $9.2 \%$ \\
\hline 3 & Recommendations & $13.8 \%$ & $27.6 \%$ & $58.6 \%$ & $17.1 \%$ & $42.1 \%$ & $40.8 \%$ \\
\hline 4 & Coach & $27.6 \%$ & $56.9 \%$ & $15.5 \%$ & $22.4 \%$ & $50.0 \%$ & $27.6 \%$ \\
\hline 5 & Quality of sports services & $13.8 \%$ & $60.3 \%$ & $25.9 \%$ & $23.7 \%$ & $56.6 \%$ & $19.7 \%$ \\
\hline 6 & Price of sports services & $15.5 \%$ & $50.0 \%$ & $34.5 \%$ & $17.1 \%$ & $34.2 \%$ & $48.7 \%$ \\
\hline 7 & $\begin{array}{l}\text { Ratio of quality and price of } \\
\text { sports services }\end{array}$ & $25.9 \%$ & $44.8 \%$ & $29.3 \%$ & $19.7 \%$ & $40.8 \%$ & $39.5 \%$ \\
\hline 8 & Popularity of sports activity & $12.1 \%$ & $12.1 \%$ & $75.9 \%$ & $11.8 \%$ & $11.8 \%$ & $76.3 \%$ \\
\hline 9 & Child's ability & $36.2 \%$ & $36.2 \%$ & $27.6 \%$ & $35.5 \%$ & $31.6 \%$ & $32.9 \%$ \\
\hline
\end{tabular}


penditure in this category. Although more than half (74 subjects) had not insured their children, for 37 subjects, the average children's health insurance costs amounted to EUR 20-40. Sports camps are usually organized during the summer break; therefore, 124 subjects had not incurred expenses for sports camps. Although 46 subjects had not incurred expense for food supplements and vita- mins, three significant categories by costs were observed: up to EUR 10 (24 subjects), EUR 11-20 (24 subjects), and EUR 21-30 (27 subjects).

In summary, it can be stated that the average parental costs for children's sports activities per 9 months amount to EUR 550 consisting of the membership fees and other costs.

\section{CONCLUSION}

Local policymakers and managers of physical activity and sports services should be aware of the necessity to calculate consumer spending in sport. As Davies (2010) indicated, usually spending on sport-related goods and services is underestimated due to methodological reasons.

The statistical analysis done to determine the statistical significance by household income had not revealed any differences. Parents tend to finance children's non-formal education through sports irrespective of household income, i.e., parental predispositions towards their children's participation in sports are much stronger compared to incurred expenses on sports activities. The analysis of non-formal sports education club, sport, or activity selection criteria also had not revealed any statistically reliable difference. According to Lera-López and Rapún-Gárate (2007), neither low levels of education nor personal income are barriers to the practice of the sport. Moreover, Kokolakakis, Lera-López, and Castellanos (2014) suggested developing sports activities for the whole family, fine-tune the policy according to the regional characteristics and intervening in education and youth sport. In conclusion, the consistency of the questionnaire should be checked, or the survey should be repeated with a larger representative sample of respondents.

\section{REFERENCES}

1. Adaškevičienè, E., \& Strazdienè, N. (2013). Mokinių fizinio aktyvumo didinimo pedagoginès strategijos sveikatos požiūriu. Sportinį darbingumą lemiantys veiksniai. Moksliniu straipsniu rinkinys, 6-15.

2. Aidukaite, J. (2009) The Transformation of Welfare Systems in the Baltic States: Estonia, Latvia and Lithuania. In Cerami \& Vanhuysse (Eds.), PostCommunist Welfare Pathways. London: Palgrave Macmillan.

3. Balvočiūtè, R. (2014). Changes in Income Inequality in the EU Countries in 2005-2011. Economics and Business, 25(1), 6-11. Retrieved from https:// ortus.rtu.lv/science/en/ publications/18615-Changes + in + Income+Inequality $+\mathrm{in}+\mathrm{t}$ he+EU+Countries+in +2005+ \%E2\%88\%92+2011
4. Barkauskaitè, M. (2004). Moksleivių dorinis ugdymas popamokineje veikloje. Pedagogika, 72, 21-25.

5. Camiré, M., Trudel, P., \& Forneris, T. (2014). Examining How Model Youth Sport Coaches Learn to Facilitate Positive Youth Development. Physical Education and Sport Pedagogy, 19(1), 1-17. https://doi.org/10.1080/17408989. 2012.726975

6. Candemir, A., \& Zalluhoğlu, A. E. (2012). Factors Affecting the Sport Related Consumer Expenditures. Ege Academic Review, 12, 29-39. Retrieved from https://econpapers. repec.org/article/egejournl/v_3a12 _3ay_3a2012_3ai_3aspecialissue_. 3ap_3a29-39.htm

7. Celik, S., \& Ozerkek, Y. (2009). Panel Cointegration Analysis of Consumer Confidence and Personal Consumption in the European Union. Journal of Business Economics and Management, 10(2), 161-168. https://doi.org/10.3846/16111699.2009.10.161-168

8. Čingienè, V. (2015). Lietuvos gyventoju vartojimo išlaidy sporto sektoriuje analize. Kaunas: Unikom.

9. Davies, L. E. (2002). Consumers' Expenditure on Sport in the UK: Increased Spending or Underestimation? Managing Leisure, 7(2), 83-102.

10. Education and Training 2010 Work Program. European Parliament Resolution of 18 December 2008.

11. European Commission (2007). White Paper on Sport Brussels. European Commission.

12. Eurostat Statistics Explained (2016). Minimum Wage Statistics. 
Retrieved from https://ec.europa. eu/eurostat/statistics-explained/ index.php/Minimum_wage_statistics

13. Gratton, Ch., \& Taylor, P. (1988) Economics of Leisure Services Management. Harlow: Longman Group ltd.

14. Kokolakakis, Th., Lera-López, F., \& Castellanos, P. (2014). Regional differences in sports participation: the case of Local Authorities in England. International Journal of Sport Finance, 9(2), 149-171. Retrieved from https://www.researchgate. net/publication/286007268_Regional_Differences_In_Sports_ Participation_The_Case_of_Local_Authorities_in_England

15. Kvieskienė, G., \& Petronienè, O. (2007). Neformaliojo vaikų švietimo sąnaudos ir prieinamumas. Socialinis ugdymas, 3(14), 60-78.

16. Lamb, L., Asturias, L., Roberts, L. P. K., \& Ve Brodie, D. A. (1992). Sports Participation - How Much Does It Cost? Leisure Studies, 11(1), 19-29. https://doi. org/10.1080/02614369100390281

17. Lenartowicz, M. (2013). Family Leisure Consumption and Youth Sport Socialization in Post-communist Poland: A Perspective Based on Bourdieu's Class Theory. International Review for the Sociology of Sport, 51(2), 219-237. https://doi.org/10.1177\%2F1012690213516619

18. Lera-López, F., \& Rapún-Gárate, M. (2007). The Demand for Sport: Sport Consumption and Participation Models. Journal of Sport Management, 21(1), 103-122. Retrieved from https:// www.researchgate.net/publication/285027384_The_Demand_ for_Sport_Sport_Consumption_ and_Participation_Models

19. Lisauskaitè, V. (2010). Lietuvos gyventojų pajamų ir vartojimo diferenciacija. Verslas: teorija ir praktika, 11(3), 266-278. Retrieved from https://www.researchgate. net/publication/270981106_Lietuvos_gyventoju_pajamu_ir_vartojimo_diferenciacija
20. Lydeka, Z., \& Žaliauskas, Ž. D. (2013). Veiksnių, turinčių ịtakos Lietuvos valstybès išlaidoms ir ju struktūroms tyrimas. Taikomoji ekonomika: sisteminiai tyrimai, 7(1), 13-29. Retrieved from https://www.vdu.lt/cris/handle/20.500.12259/1245

21. Moldovan, O., \& Bocoş-Binţinţan, V. (2015). The Necessity of Considering the Concept of nonformal education. Procedia - Social and Behavioral Sciences, 209, 337-343. https://doi.org/10.1016/j. sbspro.2015.11.245

22. Morkūnienè, A. (2012). Neformaliojo vaiku švietimo kaitos nuostatos. Vilnius: Ugdymo plètotés centras.

23. National Education Strategy 20132022. Valstybinè švietimo 2013 2022 metu strategija, 2013.

24. Preuss, H., \& Alfs, C. (2013). Wirtschaftliche Bedeutung des Sportkonsums in Deutschland. Sportwissenschaft, 43(4), 239252. Retrieved from https:// www.researchgate.net/publication/278674704_Wirtschaftliche_Bedeutung_des_Sportkonsums_in_Deutschland

25. Preuss, H., Alfs, C., \& Ahlert, G. (2012). Economic Dimensions of Sport Consumption in Germany. Executive Summary.

26. Putys, T. (2015, gruodžio 2 d.). Neformaliojo vaiku švietimo lèšu skyrimo ir panaudojimo tvarkos aprašo igyvendinimo savivaldybèse apžvalga. Pranešimas konferencijoje, Švietimo ir mokslo ministerija, Vilnius.

27. Ruškus, J., Žvirdauskas, D., \& Stanišauskienè, V. (2009). Neformalusis švietimas Lietuvoje. Faktai, interesai, vertinimai. Vilnius: Švietimo aprūpinimo centras.

28. Skirmantienè, J. (2013). Neformaliojo ugdymo reikšmé pozityviajai socializacijai. Socialine teorija, empirija, politika ir praktika, 7, 118-116.

29. Statistikos departamentas. (2016). Namų ükiai ir šeimos, jų sudetis ir dydis.

30. Summers, J., Johnson, M. M., \& Ve Kanoyangwa, R. (2007). Teenage
Motivations for Sport Related Consumption in Australia. In P. G. Pitts (Eds.), Sport Marketing in the New Millennium, U.S, Fitness Information Technology Inc.

31. Taks, M., Renson, R., \& Ve Vanreusel, B. (1999). Consumer Expenses in sport: a marketing tool for sports and sports facility providers? European Journal for Sport Management, 6(1), 4-18. Retrieved from https://www. semanticscholar.org/paper/Consumer-expenses-in-sport\%3A-amarketing-tool-for-Taks-Renson/7 4556dd4a83100ee3c35d6776dc9ce $1 \mathrm{fdb} 2 \mathrm{~d} 61 \mathrm{f} 1$

32. The Ministry of Economy of the Republic of Lithuania (n.d.). Lithuania: National Reform Programme, 2011.

33. Vaikų ir Jaunimo Socializacijos Programa. Lietuvos Respublikos Vyriausybès $2010 \mathrm{~m}$. spalio $11 \mathrm{~d}$. isakymas, Nr. V-1715.

34. Wicker, P., Breuer, C., \& Pawlowski, T. (2010). Are Sports Club Members Big Spenders?: Findings from Sport Specific Analyses in Germany. Sport Management Review, 13(3), 214224. https://doi.org/10.1016/j. smr.2009.07.001

35. Žygaitienė, B., \& Sinkevičienè, J. (2015). Neformalusis technologinis vaikų ugdymas Vilniaus mieste. Pedagogika, 3, 60-72. Retrieved from https://www.vdu.lt/cris/handle/20.500.12259/98118 